\title{
HEROES IN A VACUUM: THE APOLLO ASTRONAUT AS CULTURAL ICON
}

\author{
Roger D. Launius* \\ Smithsonian Institution, Washington, DC 20650
}

\begin{abstract}
I. Abstract
Through this essay I shall explore the creation and sustaining of the iconographic mythology of the Apollo astronaut in American culture. No one could have predicted the public fascination with astronauts from the first unveiling of the Mercury seven in 1959 through Project Apollo. The astronaut as a celebrity and what that has meant in American life never dawned on anyone beforehand. To the surprise and ultimately consternation of some NASA leaders, they immediately became national heroes and the leading symbols of the fledgling space program. Even so, both NASA and the press contrived to present the astronauts as embodiments of the leading virtues of American culture and this has continued from the 1950s to the new millennium. Both NASA officials and the astronauts themselves carefully molded and controlled their public images every bit as successfully as those of movie idols or rock music stars. ${ }^{1}$ What follows is an exploration of the creation and sustaining of the iconographic mythology of the astronaut in American culture.
\end{abstract}

\section{Creation of the Myth}

Just a few days after the establishment of NASA in October 1958, the godfather of human spaceflight, Robert R. Gilruth, gained the approval of Project Mercury. Gilruth, a longtime engineer who had worked for the National Advisory Committee for Aeronautics (NACA) since the latter 1930s at the Langley Memorial Aeronautical Laboratory, had become interested in the possibilities of high speed flight in orbit just after World War II. He led the NACA's efforts in rocketry throughout the 1950s and pursued with enthusiasm possibilities of human spaceflight, gaining the creation of the Space Task Group to see the effort through to accomplishment. From his mind sprang the Mercury program, and the astronaut corps needed to accomplish it. He firmly believed that humanity's future lay beyond this planet and he intended to start society down that challenging and hopeful path. ${ }^{2}$

Concurrent with the decision to move forward with Project Mercury, NASA selected and trained the Mercury astronaut corps. ${ }^{3}$ President Dwight D. Eisenhower directed that the astronauts be selected from among the armed services' test pilot force. ${ }^{4}$ Although this had not been the NASA leadership's first choice, this decision greatly simplified the selection procedure. The inherent riskiness of spaceflight, and the potentially national security implications of the program, pointed toward the use of military personnel. It also narrowed and refined the candidate pool, giving NASA a reasonable starting point for selection. It also made imminent sense in that NASA envisioned this astronaut corps first as pilots operating experimental flying machines and only later as scientists. ${ }^{5}$ As historian Margaret Weitekamp has concluded:

From that military test flying experience, the jet pilots also mastered valuable skills that NASA wanted its astronauts to possess. Test pilots were accustomed to flying high-performance aircraft, detecting a problem, diagnosing the cause, and communicating that analysis to the engineers and mechanics clearly. In addition, they were used to military discipline, rank, and order. They would be able to take orders. Selecting military jet test pilots as their potential astronauts allowed NASA to choose from a cadre of highly motivated, technically skilled, and extremely disciplined pilots. ${ }^{6}$

In addition, since most NASA personnel in Project Mercury came out of the aeronautical research and development arena anyway, it represented almost no stretch on the agency's part to accept test pilots as the first astronauts. After all, they had been working with the likes of them for decades and knew and trusted their expertise. It also tapped into a highly disciplined and skilled group of individuals, most of whom were already aerospace engineers, who had long ago agreed to risk their lives in experimental vehicles. ${ }^{7}$

From a total of 508 service records screened in January 1959 by NASA at the military personnel bureaus in Washington, they found 110 men that met the minimum standards established for Mercury:

1. Age-less than 40 .

2. Height-less than 5' 11".

3. Excellent physical condition.

${ }^{*}$ Chair, Division of Space History, National Air and Space Museum 
4. Bachelor's degree or equivalent.

5. Graduate of test pilot school.

6. 1,500 hours total flying time.

7. Qualified jet pilot.

This list of names included five Marines, 47 Navy aviators, and 58 Air Force pilots. Several Army pilots' records had been screened earlier, but none was a graduate of a test pilot school. ${ }^{8}$ The selection process began while the possibility of piloted Mercury/Redstone flights late in 1959 still existed so time was a critical factor is the screening process, although launch before the end of the year later proved impossible.

From this initial review, the Space Task Group's Assistant Director, Charles J. Donlan, divided the list of 110 fliers into three groups and issued invitations for the first group of 35 to come to Washington at the beginning of February for briefings and interviews. Donlan's team initially planned to select twelve astronauts, but as team member George M. Low reported:

During the briefings and interviews it became apparent that the final number of pilots should be smaller than the twelve originally planned for. The high rate of interest in the project indicates that few, if any, of the men will drop out during the training program. It would, therefore, not be fair to the men to carry along some who would not be able to participate in the flight program. Consequently, a recommendation has been made to name only six finalists. ${ }^{10}$

Every one of the first ten pilots interrogated on February 2 agreed to continue through the elimination process. The next week a second third of the possible candidates arrived in Washington. The high rate of volunteering made it unnecessary to extend the invitations to the third group. By the first of March 1959, 32 pilots prepared to undergo a rigorous set of physical and mental examinations.

Thereafter each candidate went to the Lovelace Clinic in Albuquerque, New Mexico, to undergo individual medical evaluations. This involved over 30 different laboratory tests collecting chemical, encephalographic, and cardiographic data. X-ray examinations thoroughly mapped each candidate's body. The ophthalmology section and the otolaryngology sections likewise learned almost everything about each candidate's eyes, ears, nose, and throat. Special physiological examinations included bicycle ergometer tests, a total-body radiation count, total-body water determination, and the specific gravity of the whole body. Heart specialists made complete cardiological examinations, and other clinicians worked out more complete medical histories on these men than probably had ever before been attempted on human beings. ${ }^{11}$

Phase four of the selection program involved passing an amazingly elaborate set of environmental studies, physical endurance tests, and psychiatric studies conducted at the Aeromedical Laboratory of the Wright Air Development Center, Dayton, Ohio. During March 1959 each of the candidates spent another week in pressure suit tests, acceleration tests, vibration tests, heat tests, and loud noise tests. Continuous psychiatric interviews, the necessity of living with two psychologists throughout the week, an extensive self-examination through a battery of thirteen psychological tests for personality and motivation, and another dozen different tests on intellectual functions and special aptitudes - these were all part of the Dayton experience. ${ }^{12}$

Sometimes the would-be astronauts played mind games with their psychologists. Although he had applied during the search for the first Mercury astronauts 1959, Charles "Pete" Conrad did not achieve his goal at that time. He always believed he failed because he was too flippant when meeting psychologists who were screening the candidates. Conrad's sense of humor became legendary at NASA, and many people considered him their favorite astronaut because of his wit, charisma, and humor. As Conrad liked to say, "If you can't be good, be colorful." Conrad enjoyed telling the story, which seemed to get better with every rendition, that when a psychologist showed him a blank white card and asked him to describe what he saw, he replied that it was "upside down." He was later successful and came to NASA as an astronaut in September 1962 in the second class of astronauts brought in to fly during Project Gemini. ${ }^{13}$

Finally, without conclusive results from these tests, late in March 1959 Robert R. Gilruth's Space Task Group began phase five of the selection, narrowing the candidates to eighteen. Thereafter, final criteria for selecting the candidates reverted to the technical qualifications of the men and the technical requirements of the program, as judged by Charles Donlan and his team members. "We looked for real men and valuable experience," said Donlan, and he pressed Gilruth to select the epitome of American masculinity. ${ }^{14}$ Gilruth finally decided to select seven. The seven men became heroes in the eyes of the American public almost immediately; in part due to a deal they made with Life magazine for exclusive rights to their stories, and errantly became the personification of NASA to most Americans. ${ }^{15}$

Despite the wishes of the NASA leadership, the fame of the astronauts quickly grew beyond all proportion to their activities. Perhaps it was inevitable that the astronauts were destined for premature adulation, what with the enormous public curiosity about them, the risk they would take in spaceflight, and their exotic training activities. But the power of commercial competition for publicity and the pressure for political prestige in the space race also whetted an insatiable public appetite for this new kind of celebrity. Walt Bonney, long a public information officer for NACA and in 1959 
NASA's chief adviser on these matters, foresaw the public and press attention, asked for an enlarged staff, and laid the guidelines for public affairs operations that could maximize the significance of the astronauts as celebrities. ${ }^{16}$

Bonney's foresight proved itself in 1959 only a week before the cherry blossoms bloomed along the tidal basin in Washington, D.C., drenching the city on spectacular spring colors. NASA had chosen to unveil the first Americans to fly in space on April 9, 1959. This event made the astronauts public figures. Beforehand, they were a crew-cut, militaryminded, mad-monk, thrill-seeking, hard-drinking, woman-chasing, flying-fool gang of daredevils. Now, suddenly, they became heroes of a nation. Excitement bristled in Washington at the prospect of learning who those space travelers might be. Surely they were the best the nation had to offer, modern versions of Medieval knights of the Round Table whose honor and virtue was beyond reproach. Certainly, they carried on their shoulders all of the hopes and dreams and best wishes of a nation as they engaged in single combat the ominous specter of communism. The fundamental purpose of Project Mercury was to determine whether or not humans could survive the rigors of liftoff and orbit in the harsh environment of space. From this perspective, the astronauts were not comparable to earlier explorers who directed their own exploits. Comparisons between them and Christopher Columbus, Admiral Richard Byrd, and Sir Edmund Hillary left the astronauts standing in the shadows. ${ }^{17}$

NASA's makeshift headquarters was abuzz with excitement. Employees had turned the largest room of the second floor, once a ballroom, into a hastily set up press briefing room. Inadequate for the task, print and electronic media jammed into the room to see the first astronauts. One end of the room sported a stage complete with curtain, and both NASA officials and the newly chosen astronauts waited behind it for the press conference to begin at 2:00 p.m. The other end had trip hazards of electrical cable strewn about the floor, banks of hot lights mounted to illuminate the stage, and more than a few television cameras that would be carrying the event live and movie cameras recording footage for later use. News photographers gathered at the foot of the stage, and journalists of all stripes occupied seats in the gallery. Inadequate for the media jamming into the ballroom, NASA employees brought in more chairs and tried to make the journalists as comfortable as possible in the cramped surroundings. ${ }^{18}$

NASA Administrator T. Keith Glennan failed to appreciate the excitement that the revealing of the astronauts sparked. These astronauts about to be introduced-from the Marine Corps, Lt. Col. John H. Glenn, Jr.; from the Navy, Lt. Cdr. Walter M. Schirra, Jr., Lt. Cdr. Alan B. Shepard, Jr., and Lt. M. Scott Carpenter; and from the Air Force, Capt. L. Gordon Cooper, Capt. Virgil I. "Gus" Grissom, and Capt. Donald K. "Deke" Slayton-were all career officers with more than their share of bravado and skill. But they were asked to serve essentially as specimens for biomedical experiments on rockets above the Earth's atmosphere. ${ }^{19}$

Glennan served as ringmaster for a circus-like press conference to introduce those astronauts. The role did not suit him, and furthermore, he did not comprehend the excitement. But he would play his role. As he watched the seven young men chosen as astronauts at the conclusion of the lengthy selection process take their seats, none of them yet forty years old but all with more than a lifetime's worth of exciting memories. For all of them, he realized, it was the most important event of their lives. But what did it portend, honor and glory or death and contrition? Either seemed likely to Glennan on that bright April afternoon, for NASA's ability to fly people in space seemed somehow distant and fraught with folly despite all the efforts made thus far. ${ }^{20}$

Many of the Mercury seven astronauts have recorded their recollections of this singular event, and all expressed the same hesitation and dread that Glennan experienced. They also expressed irritation at the huge and unruly audience assembled for the press conference. Alan Shepard and Deke Slayton had a brief conversation as they sat down at the table behind the curtain and contemplated the event ahead:

"Shepard," Deke leaned toward him. "I'm nervous as hell. You ever take part in something like this?"

Alan grinned. "Naw." He raised an eyebrow. "Well, not really. Anyway, I hope it's over in a hurry."

"Uh huh. Me, too," Deke said quickly. ${ }^{21}$

When the curtains went up NASA public affairs officer par excellence Walter Bonney announced:

Ladies and gentlemen, may I have your attention, please. The rules of this briefing are very simple. In about sixty seconds we will give you the announcement that you have been waiting for: the names of the seven volunteers who will become the Mercury astronaut team. Following the distribution of the kit—and this will be done as speedily as possible - those of you who have p.m. deadline problems had better dash for your phones. We will have about a ten- or twelve-minute break during which the gentlemen will be available for picture taking. ${ }^{22}$

Like a dam breaking a sea of photographers moved forward and popped flashbulbs in the faces of the Mercury seven astronauts. A buzz in the conference room rose to a roar as this photo shoot proceeded. Some of the journalists bolted for the door with the press kit to file their stories for the evening papers, others ogled the astronauts.

Fifteen minutes later Bonney brought the room to order and asked Keith Glennan to come out and formally introduce the astronauts. Glennan offered a brief welcome and added, "It is my pleasure to introduce to you —and I consider it a very real honor, gentlemen-Malcolm S. Carpenter, Leroy G. Cooper, John H. Glenn, Jr., Virgil I. Grissom, Walter M. Schirra, Jr., Alan B. Shepard, Jr., and Donald K. Slayton...the nation's Mercury Astronauts!” These personable pilots 
faced the audience in civilian dress, and many people in their audience forgot that they were volunteer test subjects and military officers. Rather they were a contingent of mature middle class Americans, average in build and visage, family men all, college-educated as engineers, possessing excellent health, and professionally committed to flying advanced aircraft. $^{23}$

The reaction was nothing short of an eruption. Applause drowned out the rest of the NASA officials' remarks. Journalists rose to their feet in a standing ovation. Even the photographers crouched at the foot of the stage rose in acclamation of the Mercury Seven. A wave of excitement circulated through the press conference like no one at NASA had never seen before. What was all of the excitement about?

The astronauts asked themselves the same question. Slayton nudged Shepard and whispered in his ear, "They're applauding us like we've already done something, like we were heroes or something." It was clear to all that Project Mercury, the astronauts themselves, and the American space exploration program was destined to be something extraordinary in the nation's history. ${ }^{24}$

The rest of the press conference was as exuberant as the introduction. At first the newly selected astronauts replied to the press corps' questions with military stiffness, but led by an effervescent and sentimental John Glenn they soon warmed to the interviews. What really surprised the astronauts, however, was the nature of the questions most often asked. The reporters did not seem to care about their flying experience, although all had been military test pilots, many had combat experience and decorations for valor, and some held aircraft speed and endurance records. They did not seem to care about the details of NASA's plans for Project Mercury. What interested them greatly, however, were the personal lives of the astronauts. The media wanted to know if they believed in God and practiced any religion. They wanted to know if they were married and the names and ages and gender of their children, they wanted to know what their families thought about space exploration and their roles in it, and they wanted to know about their devotion to their country. God, country, family, and self, and the virtues inherent in each of them, represented the sum total of the reporters' interests. ${ }^{25}$

It was an odd press conference, the reporters probing the character of the pilots. But the motivations were never to dig up dirt on the astronauts, as has so often been the case with the media since and were certainly something they could have profitably done with these men; instead it was just the opposite. The reporters wanted confirmation that these seven men embodied the deepest virtues of the United States. They wanted to demonstrate to their readers that the Mercury seven strode the Earth as latter-day saviors whose purity coupled with noble deeds would purge this land of the evils of communism by besting the Soviet Union on the world stage. The astronauts did not disappoint.

John Glenn, perhaps intuitively or perhaps through sheer zest and innocence, picked up on the mood of the audience and delivered a ringing sermon on God, country, and family that sent the reporters rushing to their phones for rewrite. He described how Wilbur and Orville Wright had flipped a coin at Kitty Hawk in 1903 to see who would fly the first airplane and how far we had come in only a little more than fifty years. "I think we would be most remiss in our duty," he said, "if we didn't make the fullest use of our talents in volunteering for something that is as important as this is to our country and to the world in general right now. This can mean an awful lot to this country, of course." The other astronauts fell in behind Glenn and eloquently spoke of their sense of duty and destiny as the first Americans to fly in space. It was a magnificent press conference! Near the end of the meeting, a reporter asked if they believed they would come back safely from space and all raised their hands. Glenn raised both of his. ${ }^{26}$

The astronauts emerged as noble champions who would carry the nation's manifest destiny beyond its shores and into space. James Reston of the New York Times, a newspaper with a history of pooh-poohing space flight going back to a criticism of Robert Goddard in 1920, exulted the astronaut team. He said he felt profoundly moved by the press conference, and even reading the transcript of it made one's heart beat a little faster and step a little livelier. "What made them so exciting," he wrote, "was not that they said anything new but that they said all the old things with such fierce convictions...They spoke of 'duty' and 'faith' and 'country' like Walt Whitman's pioneers...This is a pretty cynical town, but nobody went away from these young men scoffing at their courage and idealism.".27

The astronauts put a very human face on the grandest technological endeavor in history and the myth of the virtuous, no-nonsense, able, and professional astronaut was born at that moment in 1959. In some respects it was a natural occurrence. The Mercury Seven were, in essence, each of us. None were either aristocratic in bearing or elitist in sentiment. They came from everywhere in the nation, excelled in the public schools, trained at their local state university, served their country in war and peace, married and tried to make lives for themselves and their families, and ultimately rose to their places on the basis of merit. They represented the best we had to offer, and most important they expressed at every opportunity the virtues ensconced in the democratic principles of the republic.

The press was fascinated by the apparent willingness to risk their lives for the good of a national cause. Tom Wolfe captured the mythological dimension of the astronaut in The Right Stuff. Describing that first press conference, Wolfe cut to the essential question that the reporters kept circling around. Were the astronauts afraid they were going to die? "They had volunteered to sit on top of rockets-which always blew up! They were brave 
lads who had volunteered for a suicide mission!...And all the questions about wives and children and faith and God and motivation and the Flag...they were really questions about widows and orphans...and how a warrior talks himself into going on a mission in which he is bound to die." ${ }^{28}$ The astronauts put forward a brave, determined image that did much to galvanize support for the program they represented.

For one, Project Mercury manager Robert R. Gilruth understood very well that the astronauts were critical to the success of NASA's space efforts. Early on he made astronauts an important part of the organizational structure; inviting them into the inner councils of NASA and into the decision-making process. Gilruth recalled in 1987: "They certainly had every right to sit in and listen to things that were going on in the design of the spacecraft. They certainly had every right to make an input." In essence, Gilruth put the astronauts to work for him, co-opting them on behalf of his larger ideals. "People used to tell me that I had no control over the astronauts," Gilruth commented. "I'll tell you, those boys were wonderful." ${ }^{, 2}$ The bravery of the astronauts touched emotions deeply seated in the American experience of the twentieth century, felt by Gilruth perhaps most of all. He remained friends with them-but also in awe of them-his entire life. He was not alone. When asked how critical the early astronauts were in defining the space program for NASA, one might note that no one ever gave a ticket tape parade to a robotic spacecraft, despite their very significant accomplishments ${ }^{30}$

The Mercury Seven astronauts defined the myth of the astronaut. The creation of the myth of the astronaut as everyman, forged in the earliest history of the astronaut corps, reached its pentacle in the Apollo era, in part because of the makeup of that corps.

\section{The Demographics of the Astronaut Corps}

The Mercury Seven astronauts defined the myth of the astronaut. In so doing there have been five basic components that emerge as central to this mythology.

- The astronaut as "everyman," in a Frank Capra-esque manner that imbibed all the positive attributes of the national identity. He personified the ordinary American in every town in the nation-the good neighbor, the Samaritan that stops to help a stranded motorist, the husband and father who coaches the kids' baseball team, the worshipper in the neighborhood church, the non-partisan working at the polls anxious to ensure democratic elections, the trusted friend, the loyal employee, the civic-minded citizen who chaperoned his children on a tour of the nation's capital and in the process imparted to the next generation an understanding of the virtues of American civilization. He was the epitome of establishment virtue, the Ward Cleaver of "Leave it to Beaver" or Ozzie Nelson of "Ozzie and Harriet."

- The astronaut as defender of the nation. Like Cincinnatus at the plow, the astronaut came from the ranks of the nation's mainstream to defend the nation against an aggressive empire bent on the destruction of the way of life of the "everyman." He came not for personal fame and fortune, although all recognized that success would ensure that as well, but for the good of the civilization. He willingly put himself in danger for the good of all. When victory was assured he would, like Cincinnatus of Rome—or George Washington of the United States-he would return to his quiet life.

- The astronaut as fun-loving young man. He enjoyed his family and friends, and he enjoyed speed and automobiles and flying. The propensity for fun, in the best sense of the term, became an important part of the mystique of the astronaut.

- The astronaut as a virile, masculine representative of the American ideal. Young, in excellent physical shape, engaged in a strenuous and dangerous activity, the astronauts personified youth and vigor.

- The astronaut as hero. As a media made celebrity even before accomplishing anything of note, the astronauts could be likened to sports and entertainment idols manufactured for public consumption. Like those other idols, however, to remain a hero they had to attain great feats. They did so, and even when there were circumstances that might reflect unfavorably on them, also like those other idols, they were kept from the public as much as possible.

The creation of the myth of the astronaut as everyman, forged in the earliest history of the astronaut corps, reached its pinnacle in the Apollo era, in part because of the makeup of that corps.

Perhaps the most striking feature of the first astronauts was their mainstream Euro-American maleness. Overwhelmingly, the astronauts of the Apollo era were white males of middle class, military veteran, state university educated backgrounds. Most were middle-western, the children of working class parents who were the first members of their families to attend college. They went to the public schools, not prep schools, and often attended college on the GI bill after having served in the military during World War II. Almost all were family men, with wives and children. Few were from what might be considered privileged backgrounds. Only Charles "Pete" Conrad was from an Ivy League school, Princeton University, and in his case he went to great extremes to seem ordinary by playing the clown. ${ }^{31}$ 
Numerous examples of this dynamic abound. For example, Alan B. Shepard Jr., the first American in space in 1961 and the commander of the Apollo 14 mission in 1971, was born in 1923 in East Derry, New Hampshire. Educated in public schools and the United States Naval Academy in Annapolis, Maryland, between 1941 and 1945, Shepard became a career officer, first on a destroyer and later as a naval aviator. Shepard's exploits as an astronaut were among the most significant scientific endeavors of the recent past. His actions as the first American to ride a rocket into space made him not just a celebrity, which he became because of the American people's interest in manned spaceflight and NASA's deft public relations, but also a frontiersman in the same mold as Lewis and Clark. His actions as one of seven "point men," the seven Mercury astronauts, for the American space program served to unify a nation behind a great opportunity, the exploration of space. His May 5, 1961, suborbital Mercury mission established that the United States could send to and recover from space an individual. It was an enormously significant event for the United States. Only recently had the nation been shocked by several outstanding space exploits from its closest rival, the Soviet Union - the 1957 orbiting of the Sputnik satellite, and the Yuri Gagarin space flight—and there was much impetus to rescue national honor in the U.S.' own space program. The flight made of Shepard a national hero, but his stoical persona and public countenance also served to solidify his stature among Americans as a role model..$^{32}$

Shepard's other great space flight took place on January 31-February 9, 1971, a decade later. (A medical disorder had kept him off flight status for several years.) Shepard commanded Apollo 14 on a lunar landing mission at a significant time, a few months after the near-tragic Apollo 13 mission in which the lunar lander had been used as a "lifeboat" for the crew. His mission, a complete success, boosted the national spirit and restored faith in the Apollo program. The achievements of Apollo 14 were many: first use of the Mobile Equipment Transporter; placement of the largest payload ever in lunar orbit; longest stay on the lunar surface (33 hours); longest lunar surface EVA (9 hours and 17 minutes); first use of shortened lunar orbit rendezvous techniques; first use of color television on the lunar surface; first extensive orbital scientific experimentation period conducted in lunar orbit; and even the first lunar golf game (Shepard, an avid golfer, hit a hole in one). Shepard's essential humanity came through in this effort, as he accepted his role as an American icon, but one who is "everyman" answering the call of his nation. ${ }^{33}$

As another example, Frank Borman was born and raised near Gary, Indiana, in 1928. He attended the public schools and graduated from the U.S. Military Academy at West Point in 1950 and entered the Air Force, where he became a fighter pilot. From 1951 to 1956 he was assigned to various fighter squadrons. After completing a M.S. in aeronautical engineering, in 1957 he became an instructor of thermodynamics and fluid mechanics at West Point. On 17 September 1962, Borman became an astronaut with NASA and commanded the Gemini VII mission launched in December 1965, where he participated in the longest space flight to that time (330 hours and 35 minutes) and the first rendezvous of two maneuverable spacecraft.

Borman's most significant space mission was as commander of the Apollo 8 mission, which flew around the Moon over the Christmas holidays of December 1968. Initially it was planned as a mission to test Apollo hardware in low-Earth orbit, but NASA officials took a calculated risk to expand it into a circumlunar flight. As Apollo 8 traveled outward, the crew focused a portable television camera on Earth and for the first time humanity saw its home from afar. Some people have suggested that the modern environmental movement was aided in its effort by these images of a fragile planet surrounded by total bleakness. When Apollo 8 arrived at the Moon on Christmas Eve, this image of Earth was even more strongly reinforced when Borman sent back images of the planet while reading the first part of the Bible- "God created the heavens and the Earth, and the Earth was without form and void"-before sending Christmas greetings. The flight returned to Earth on December 27, 1968. An important accomplishment, this flight united the nation, coming as it did at a time when American society was in crisis, over Vietnam, race relations, and social unrest. ${ }^{34}$

Finally, Neil Armstrong was born on August 5, 1930, on his grandparents' farm near Wapakoneta, Ohio. His parents were Stephen and Viola Armstrong. Because Stephen Armstrong was an auditor for the state of Ohio, Neil grew up in several Ohio communities, including Warren, Jefferson, Ravenna, St. Marys, and Upper Sandusky, before the family settled in Wapakoneta. He developed an interest in flying at age two when his father took him to the National Air Races in Cleveland, Ohio. His interest intensified when he had his first airplane ride in a Ford Tri-Motor, a "Tin Goose," in Warren, Ohio, at age 6. From that time on, he claimed an intense fascination with aviation. At age 15 Armstrong began taking flying lessons at an airport north of Wapakoneta, working at various jobs in town and at the airport to earn the money for lessons in an Aeronca Champion airplane. By age 16 he had his student pilot's license; this was before passing his driver's test and receiving that license and before graduating from Blume High School in Wapakoneta in 1947.

Immediately after high school Armstrong received a scholarship from the U.S. Navy. He enrolled at Purdue University and began to study aeronautical engineering. In 1949 the Navy called him to active duty, during which he became an aviator. In 1950 he was sent to Korea, where he flew 78 combat missions from the aircraft carrier USS Essex. After mustering out of the Navy in 1952, Armstrong joined the National Advisory Committee for 
Aeronautics (NACA). His first assignment was at NACA's Lewis Research Center near Cleveland, Ohio. For the next 17 years he worked as an engineer, test pilot, astronaut, and administrator for NACA and its successor agency, NASA.

In the mid-1950s Armstrong transferred to NASA's Flight Research Center in Edwards, California, where he became a research pilot on many pioneering high-speed aircraft-including the well-known X-15, which is capable of achieving a speed of 4,000 mph. He flew over 200 different models of aircraft, including jets, rockets, helicopters, and gliders. He also pursued graduate studies and received a M.S. degree in aerospace engineering from the University of Southern California. Armstrong transferred to astronaut status in 1962, one of nine NASA astronauts in the second class to be chosen. He moved to El Lago, Texas, near Houston's Manned Spacecraft Center, to begin his astronaut training. There he underwent four years of intensive training for the Apollo program to land an American on the Moon before the end of the decade.

On March 16, 1966, Armstrong flew his first space mission as command pilot of Gemini VIII with David Scott. During that mission Armstrong piloted the Gemini VIII spacecraft to a successful docking with an Agena target spacecraft already in orbit. Although the docking went smoothly and the two craft orbited together, they began to pitch and roll wildly. Armstrong was able to undock the Gemini and used retro rockets to regain control of his craft, but the astronauts had to make an emergency landing in the Pacific Ocean.

As spacecraft commander for Apollo 11, the first piloted lunar landing mission, Armstrong gained the distinction of being the first person to land on the Moon and the first to step on its surface. On July 16, 1969, Armstrong, Michael Collins, and Edwin E. "Buzz" Aldrin began their trip to the Moon. Collins was the command module pilot and navigator for the mission. Aldrin, a systems expert, was the lunar module pilot and became the second man to walk on the Moon. As commander of Apollo 11, Armstrong piloted the lunar module to a safe landing on the Moon's surface. On 20 July 1969, at 10:56 P.M. EDT, Neil Armstrong stepped down onto the Moon and made his famous statement, "That's one small step for [a] man, one giant leap for mankind." Armstrong and Aldrin spent about two and one-half hours walking on the Moon collecting samples, doing experiments, and taking photographs. On 24 July 1969, the module carrying the three men splashed down in the Pacific Ocean. They were picked up by the aircraft carrier USS Hornet.

The three Apollo 11 astronauts were honored with a ticker-tape parade in New York City soon after returning to Earth. Armstrong received the Medal of Freedom, the highest award offered to a U.S. civilian. Armstrong's other awards following the Apollo 11 mission included the NASA Distinguished Service Medal, the NASA Exceptional Service Medal, 17 medals from other countries, and the Congressional Space Medal of Honor. ${ }^{35}$

The experience of these three astronauts is emblematic of all those who went to the Moon during Project Apollo. Their backgrounds and career paths were similar and representative of the mainstream of America. Was this an intentional development by NASA or the serendipity? Probably it was a little bit of both. But at sum it served as an important consensus-building element in the national space program. Most Americans could identify with those men from the middle class, college educated at state universities or military service academies, and emblematic of what we view as important for our national well-being. Nothing points up this consensus more effectively than a political cartoon published at the time of the Apollo 17 mission to the Moon in December 1972. It showed two African Americans watching Gene Cernan and Jack Schmitt on the Moon, and the caption read, "Maybe we'll go next time." Apollo 17, of course, was the last of the Apollo missions to the Moon and no one has returned since. By highlighting the exclusion of the African American community from this epochal event, the cartoonist emphasized the AngloAmericanness of the entire episode. It was, without a doubt, a mainstream American experience typified by the backgrounds of the astronauts that marginalized racial and ethnic minorities even as it solidified traditional American virtues and perspectives. ${ }^{36}$

\section{The Mystique of the Space Suit}

Wherever astronauts go, from the beginning of the human spaceflight program to the present, they have been characterized by their uniform. Nothing sets astronauts apart from ordinary Americans more than the physical existence of a space suit. Often described as a "spacecraft for one," space suits exist as highly complex, technical systems. For the wearer of a space suit, it represents protection, a life-line extending into the depths of outer space, but for the public, who never see the space suit in person, it exists as a symbol. As such it embodies dreams and beliefs about who and what we are, and what we may become. It even goes so far as to suggest our connections to our larger environment of Earth, the Solar System, and the universe. These concepts are not just projected onto the material space suit, but are contained in its physical construction and invested in the astronauts who wear them. Consciously or subconsciously these beliefs and philosophies are constructed through spacesuit design and manufacturing and then by their use of astronauts. Once in operation the physical object projects these philosophies 
onto the world around it; literally the space suit is a highly charged, metaphysical object that affects both the wearer and the observer. The astronaut in his spacesuit accentuated the body of the individual, making those who flew on the Apollo program seem much larger than life, much stronger than they were, and much more virile than they might have been. Due to the embodied beliefs and philosophies conjured by these suits, the astronauts facilitated new possibilities of understanding for those with whom they came into contact. ${ }^{37}$

In both fact and fiction, the space suit has been a core representation of the astronaut, essentially a knight's armor worn heroically as the individual conducts his noble mission. More than any other single artifact of the Moon landing program the Apollo space suit represented the values that supported Americans going into space in the first place. It symbolized and reified the utopian desire to colonize the Solar System and make a perfect society at a new and pristine place beyond the corrupt Earth. It also stood, as cultural historian Debra Benita Shaw wrote, "as a metaphor for the transcendent power of scientific ingenuity and technological know-how....It is thus a significant icon in contemporary cultural representations of the body in both outer and terrestrial space. ${ }^{, 38}$ As an enduring icon of Apollo, the space suited astronauts on the Moon conjured images of power and masculinity far beyond that actually present. The anonymity of those astronauts, with their visors down like the Mediaeval knights made them even more mysterious and attractive. Without intending it, the space suit became synonymous with a set of values referring "to heroism and thus to the Cartesian (masculine) subject identified by the Proper Name but the Name itself becomes curiously disconnected from the individual to which it actually refers." ${ }^{39}$ At some level, therefore, the Apollo astronaut in his space suit projected the image of the hardbody of masculinity that Susan Jeffords believes became so prevalent in the 1980s, anticipating that later development by twenty years. ${ }^{40}$

By being consumed by a space suit, as Donna Haraway has pointed out, the astronaut essentially became a cyborg,as an iconic space suit established the relationship between human and machine. Cyborg ontology is a critical element of thinking about the duality of this relationship, confounding the sense in which bodies move in apposition to the technology. ${ }^{41}$ Megan Stern's analysis of visored astronauts in spacesuits suggest that they are essentially anonymous, a screen on which anyone might project any attribute from fantasies of heroism to submission. Therefore, the Apollo astronauts in their suits became screens for the whole of America to project its hopes, wishes, fears, and horrors. Each astronaut felt this keenly, as they have lived out the remainder of their lives in the glare of American fame and the sense of expectations never fully satisfied. Unable always to reflect the qualities of strength, authority, and rationality so often projected on them, the astronauts have displayed a fragility since Apollo that is both perplexing and troubling for many who see them in later years. ${ }^{42}$ Marina Benjamin described this best when she encountered three Apollo astronauts at a celebrity and collectors show. She wrote that they were "just like movie stars; they burned brightly in the glare of publicity when they were offered good parts to play and then, when the roles dried up, so did they." Their spacesuits, however, represented the triumph of technology over living organisms. ${ }^{43}$ Those suits dominate the essence of what it means to be an astronaut; they have since Apollo and continue to do so today.

\section{Astronaut Masculinity and the Crisis of Post-Modern Society}

The Apollo astronauts all had an image of hard-working, fun-loving, virile representations of masculinity. The expression of public comfort with the white male establishment is palpable throughout the recounting of the story of Apollo. The quintessential company man worked for NASA during Apollo. The engineering "geeks" of Mission Control, with their short-sleeved white shirts, narrow black ties, slide rules hung on their belts like sidearms, and their pocket protectors complete with compass and ruler and myriad pens and mechanical pencils all personified a conservative America that many looked back on with fondness and nostalgia. Even Norman Mailer, as much an embodiment of the Sixties counter-culture as anyone, ranted about this aspect of Apollo while covering the Moon landings in 1969. Mailer expressed fascination and not a little perplexity with the time warp that he witnessed at the Manned Spacecraft Center in Houston. He railed against an overwhelmingly white male NASA steeped in middle class values and reverence for the American flag and mainstream culture. Mailer grudgingly admitted, however, that NASA's approach to task accomplishment-which he viewed as the embodiment of the Protestant Work Ethic-and its technological and scientific capability got results with Apollo. Even so, he hated at NASA's closed and austere society, one where he believed outsiders were distrusted and held at arm's length with a bland and faceless courtesy that betrayed nothing. For all of his skepticism, for all of his esotericism, Mailer captures much of interest concerning rocket technology and the people who produced it in Project Apollo. ${ }^{44}$

Mailer's critique foreshadows by twenty-five years a powerful nostalgia that has grown up around Apollo as a program that was done right, in no small part because it took place within the cultural confines of an era before the social revolution of the 1960s. Nothing captures this nostalgia more effectively than the feature film, Apollo 13. Set in 1970 when an explosion crippled a lunar landing mission and NASA nearly lost astronauts Jim Lovell, Fred 
Haise, and Jack Swigert, it has been recast as one of NASA's finest hours, a successful failure. At 56 hours into the flight an oxygen tank in the Apollo service module ruptured and damaged several of the power, electrical, and life support systems. People throughout the world watched and waited and hoped as NASA personnel on the ground and the crew worked to find a way safely home. It was a close-run thing, but the crew returned safely on April 17, 1970. The near disaster served several important purposes for the civil space program-especially prompting reconsideration of the propriety of the whole effort while also solidifying in the popular mind NASA's collective genius. ${ }^{45}$ While one must give the NASA flight team high marks for perseverance, dedication, and an unshakable belief that they could bring the crew home safely, it is quite strange that no one seems to realize that the mission had already failed, and failed catastrophically, by the time of accident. ${ }^{46}$ The fact that Apollo 13 is now viewed as one of NASA's shining moments says much about the ability of humanity to recast historical events into meaningful morality plays.

In this instance, Apollo 13 became a vehicle for criticism of the social order that emerged from the 1960s and a celebration of an earlier age. When the film appeared in 1995, reviewer John Powers, writing for the Washington Post, commented on its incessant nostalgia for "the paradisiacal America invoked by Ronald Reagan and Pat Buchanan—an America where men were men, women were subservient, and people of color kept out of the way." In addition, Powers wrote, "Its story line could be a Republican parable about 1995 America: A marvelous vessel loses its power and speeds toward extinction, until it's saved by a team of heroic white men ${ }^{47}$ If anything, Powers underemphasized the white America evoked in Apollo 13. The only women with speaking parts of substance was Marilyn Lovell (Kathleen Quinlin), wife of the Apollo 13 commander, whose role is distinctly one of offering proud support while privately fearing the worst, and their daughter whose role seems to be as spokesperson for the social revolution then underway while consistently reflecting its least important elements. For example, she complains in a shriekish voice that the Beatles just broken up and that her world has accordingly collapsed.

The heroes of Apollo 13 are the geeks of Mission Control, with the astronauts aboard the spacecraft as spirited but essentially and metaphorically emasculated characters to be saved. Lovell, Haise, and Swigert must wait to be rescued in a manner not unlike Rapunzel, as an active participant but unable to accomplish the task alone. As historian Tom D. Crouch wrote of this film's depiction of the "studs" in Mission Control:

The real heroes of this film are either bald or sporting brush cuts; wear thick glasses; are partial to rumpled short sleeve shirts; and chain-smoke an endless string of cigarettes, cigars, and pipes. For all of that, these slide rulewielding technonerds solve all of the difficult problems required to bring the crew home. They are, in the words of one of the astronauts portrayed in the film, "steely-eyed missile men.,"48

Apollo 13 the film, accordingly, venerates a long past era in American history. Indeed, it may have been an era already gone by the time of the actual mission in 1970. It is a hallowing of masculinity in a nostalgic context.

A recent study completed for NASA concluded that representation of space exploration on film is highly nostalgic, and Apollo fuels that perception:

As a group, the public entertainments we tend to buy into are either nostalgic visions of the "space race" period

("The Right Stuff," "Apollo 13," "From the Earth to the Moon") or fantasies reflecting the romantic imagination of the Flash Gordon/Buck Rogers era ("Star Wars" rather than "Star Trek"). These are the visions people support in the most meaningful way possible: with their time and dollars....Boomers have a great nostalgic affection for NASA, but their own priorities have shifted from a future focus to maintaining what they have. They see money spent on space exploration as threatening their future entitlements. ${ }^{49}$

At a sublime level, the Apollo astronauts may serve as a trope for a larger lack of interest in the future expressed by Americans at the beginning of the twenty-first century. As a country, a shifting cultural center of gravity toward maintenance of the status quo rather than looking to the future has stalled a shared national vision that energized earlier efforts.

\section{Astronauts as Generational Representations}

The Apollo astronauts may also be viewed in a generational manner. Robert R. Gilruth, the director of the Manned Spacecraft Center in Houston and the "godfather" of the astronauts, look upon them as talented and rambunctious heroes that required his guidance and direction least their heroism go errant. Sometimes calling them his boys, Gilruth was an older visionary overseeing the stupendous accomplishments young and virile heroes. It is one of the most powerful conceptions in myth and human history-Merlin/King Arthur, Obi wan Kenobi/Luke Skywalker, Gandolf/Frodo Baggins, Lincoln/Union Army, FDR/G.I. generation-with the greybeard prophet teaching and motivating the young civic-minded heroes who accomplish great tasks under that guidance.

These dichotomies certainly took place in the context of the relationship between the older NASA officials and the young astronauts who went to the Moon. Gilruth was essentially a prophet, possessing vision, values, and ideals 
concerning a future for America in space. As heroes the astronauts possessed community, affluence, and technology. They made a powerful team, accomplishing the task required. NASA eventually landed six sets of astronauts on the Moon between 1969 and $1972 .^{50}$ Looked at from a generational perspective, the Apollo astronauts represented a unique cohort that served as the power and dynamism of a vision embraced and emboldened by visionary older generation.

\section{Conclusion}

Five major aspects of this mythology emerge from this analysis. The first is the creation of the myth. Arising from the first astronauts, the Mercury Seven, and sustained by the astronauts engaged in the heroic age of space exploration through Apollo, the myth has remained amazingly fixed after it took root in culture. It suggests that the astronauts established a representation of the best the U.S. had to offer the world. As American gladiators against the unknown they served as surrogates for the society that they represented. Second, the demographics of the astronaut corps-initially so static, white, male, and representative of middle class America-expanded to represent the United States in all its expansive diversity during the last quarter of the twentieth century. This transformation mythologized in its own way the astronaut and fashioned a construction of its members as emissaries of the whole population.

Third, the mystique of the space suit pointed up the difference of the astronauts from ordinary Americans. Their costumes-either in space or on the ground-have been critical to the formation and continuation of the iconography of the astronaut. Fourth, a gendered perspective on the astronauts as the epitome of masculinity early served to help create a mythology that remains to the present. Their membership in an elite "club," supported by ritual and secrecy, did much to establish the identity of the astronaut and maintain a boundary between them and the rest of society. Finally, the astronauts represented a powerful generational theme, the young, powerful warrior guided by an older, prescient, and often mystical leader or leaders who envision a wonderful future for the nation. In this context, the astronaut is making safe the way for the civilization to go forward, to progress toward a utopian future elsewhere in the cosmos.

\section{Notes}

\footnotetext{
${ }^{1}$ This is the theme of James L. Kauffman, Selling Outer Space: Kennedy, the Media, and Funding for Project Apollo, 1961-1963 (Tuscaloosa: University of Alabama Press, 1994).

${ }^{2}$ See Roger D. Launius, "Godfather to the Astronauts: Robert Gilruth and the Birth of Human Spaceflight," unpublished paper at "Realizing the Dream of Flight" symposium, Cleveland, OH, November 5, 2003.

${ }^{3}$ See, Allan C. Fisher Jr., "Exploring Tomorrow with the Space Agency," National Geographic, July 1960, pp. 48, 52-89; Kenneth F. Weaver, "Countdown for Space," National Geographic, May 1961, pp. 702-34.

${ }^{4}$ Get citation of Emme essay on the WH meeting where Ike directs that test pilots become the first astronauts. Logsdon has it for the Mercury essay in Exploring the Unknown.

${ }^{5}$ This was in striking contrast to the Soviet Union's cosmonauts, whom space program leaders believed were essentially passengers without complex tasks to perform. See Slava Gerovitch, "Trusting the Machine: The Technopolitics of Automation in the Soviet Space Program," paper presented at Society for History in the Federal Government annual meeting, October 10, 2003, copy in possession of author.

${ }^{6}$ Margaret A. Weitekamp, "The Right Stuff, The Wrong Sex: The Science, Culture, and Politics of the Lovelace Woman in Space Program, 1959-1963,” Ph.D. Diss., Cornell University, 2001, p. 98.

${ }^{7}$ In some cases this was literally the case. The best example is Neil A. Armstrong, who worked with the NACA and NASA as a civilian research pilot on the X-15 program at its Flight Research Center in the Mohave Desert prior to selection for astronaut training in 1962. For an excellent account of flight research at NACA/NASA see, Michael H. Gorn, Expanding the Envelope: Flight Research at NACA and NASA (Lexington: University Press of Kentucky, 2001).

${ }^{8}$ On this process see, Lloyd S. Swenson, James M. Grimwood, and Charles C. Alexander, This New Ocean: A History of Project Mercury (Washington, DC: NASA SP-4201, 1966), pp. 155-65; Joseph D. Atkinson, Jr. and Jay M. Shafritz, The Real Stuff: A History of NASA's Astronaut Recruitment Program (New York: Praeger Publishing, 1985), pp. 8-12.

${ }^{9}$ Atkinson and Shafritz, The Real Stuff, pp. 18, 43-45.

${ }^{10}$ Quoted in Swenson, Grimwood, and Alexander, This New Ocean, p. 161.

11 Although depicted as comic relief in the film version of The Right Stuff (1982), the battery of physiological tests were the most sophisticated designed up to that point. On these examinations see W. Randall Lovelace II, "Duckings, Probings, Checks That Proved Fliers' Fitness," Life, April 20, 1959; Mae Mills Link, Space Medicine in Project Mercury (Washington, DC: NASA SP-4003, 1965); John A. Pitts, The Human Factor: Biomedicine in the Manned Space Program to 1980 (Washington, DC: NASA SP-4213, 1985).

${ }^{12}$ Although depicted as comic relief in the film version of The Right Stuff (1982), the battery of physiological tests were the most sophisticated designed up to that point. On these examinations see W. Randall Lovelace II, "Duckings, Probings, Checks
} 
That Proved Fliers' Fitness," Life, April 20, 1959; Mae Mills Link, Space Medicine in Project Mercury (Washington, DC: NASA SP-4003, 1965); John A. Pitts, The Human Factor: Biomedicine in the Manned Space Program to 1980 (Washington, DC: NASA SP-4213, 1985).

${ }^{13}$ See Conrad's obituaries in New York Times, Los Angeles Times, Aviation Week \& Space Technology, Space News, and Washington Post for July 10, 1999, concerning his legendary impishness.

${ }^{14}$ Quoted in Swenson, Grimwood, and Alexander, This New Ocean, p. 163. The masculine ideal has been analyzed in Susan Faludi, Stiffed: The Betrayal of the American Male (New York: HarperCollins, 1999), pp. 451-68.

${ }^{15}$ See Tom Wolfe, "The Last American Hero," in Wolfe, The Kandy-Kolored Tangerine-Flake Streamline Baby (New York: Farrar, Straus, and Giroux, 1965); Atkinson and Shafritz, The Real Stuff, pp. 8-12; James L. Kauffman, Selling Outer Space: Kennedy, the Media, and Funding for Project Apollo, 1961-1963 (Tuscaloosa: University of Alabama Press, 1994), pp. 68-92; Mark E. Byrnes, Politics and Space: Image Making by NASA (Westport, CT: Praeger, 1994), pp. 25-46.

${ }^{16}$ Walter T. Bonney (1909-1975) was NASA's first director of the office of public information (1958-1960). From 1949 to 1958 he had worked for NASA's predecessor organization, the National Advisory Committee for Aeronautics, and before that, for Bell Aircraft Corp. as manager of public relations. From 1960 to 1971, he served as director of public relations for the Aerospace Corp. For information on Bonney see "Walter T. Bonney," biographical file, NASA Historical Reference Collection, NASA History Office, NASA headquarters, Washington, DC.

${ }^{17}$ On this dynamic see, Roger D. Launius, "Project Apollo in American Memory and Myth," in Stewart W. Johnson, Koon Meng Chua, Rodney G. Galloway, and Philip J. Richter, eds., Space 2000: Proceedings of the Seventh International Conference and Exposition on Engineering, Construction, Operations, and Business in Space (Reston, VA: American Society of Civil Engineers, 2000), pp. 1-13; Harvey Brooks, "Motivations for the Space Program: Past and Future," in Allan A. Needell, ed., The First 25 Years in Space: A Symposium (Washington, DC: Smithsonian Institution Press, 1983), pp. 3-26; Perry Miller, "The Responsibility of a Mind in a Civilization of Machines," The American Scholar 31 (Winter 1961-1962): 51-69; Thomas Park Hughes, American Genesis: A Century of Invention and Technological Enthusiasm, 1870-1970 (New York: Viking, 1989), p. 2.

18 "Press Conference, Mercury Astronaut Team," transcript of press conference, April 9, 1959, NASA Historical Reference Collection.

${ }^{19}$ T. Keith Glennan, The Birth of NASA: The Diary of T. Keith Glennan, J.D. Hunley, ed. (Washington, DC: NASA SP-4105, 1993), pp. 20-21. On the biomedical aspects of Mercury see, Link, Space Medicine in Project Mercury; Pitts, The Human Factor, chapter 2; Swenson, Grimwood, and Alexander, This New Ocean, pp. 446-503.

${ }^{20}$ These themes are well developed in Glennan, The Birth of NASA. See also, "Glennan Announces First Details of the New Space Agency Organization," October 5, 1958, NASA Historical Reference Collection; James R. Killian Jr., Sputnik, Scientists, and Eisenhower: A Memoir of the First Special Assistant to the President for Science and Technology (Cambridge, MA: MIT Press, 1977), pp. 141-44; James R. Killian Jr., Oral History, July 23, 1974, NASA Historical Reference Collection. Eisenhower's concerns about this aspect of modern America are revealed in his "Farewell Radio and Television Address to the American People," January 17, 1961, Papers of the President, Dwight D. Eisenhower 1960-61 (Washington, DC: Government Printing Office, 1961), pp. 103540.

${ }^{21}$ See Deke Slayton and Alan B. Shepard, Moonshot: The Inside Story of America's Race to the Moon (New York: Turner Publishing, Inc., 1994), p. 62; Roger D. Launius and Bertram Ulrich, NASA and the Exploration of Space (New York: Stewart, Tabori, and Chang, 1998), pp. 35-43, Donald K. "Deke" Slayton with Michael Cassutt, Deke! U.S. Manned Space from Mercury to Shuttle (New York: Forge Press, 1994), pp. 73-74.

22 "Press Conference, Mercury Astronaut Team," transcript of press conference, April 9, 1959, NASA Historical Reference Collection; also quoted in Launius and Ulrich, NASA and the Exploration of Space, pp. 40-41.

${ }^{23}$ The Astronauts Themselves, We Seven (New York: Simon and Schuster, 1962); William Leavitt, "First American into Orbit," Space Digest, March 1959, pp. 62-65.

${ }^{24}$ Slayton and Shepard, Moonshot, chapter 1.

25 "Space Voyagers Rarin' to Orbit," Life, April 20, 1959, p. 22

${ }^{26}$ John Glenn, with Nick Taylor, John Glenn: A Memoir (New York: Bantam Books, 1999); Space Voyagers Rarin' to Orbit," Life, April 20, 1959, p. 22.

${ }^{27}$ John H. Glenn, "A New Era: May God Grant Us the Wisdom and Guidance to Use It Wisely," Vital Speeches of the Day, March 15, 1962, pp. 324-26; Dora Jane Hamblin, "Applause, Tears and Laughter and the Emotions of a Long-ago Fourth of July," Life, March 9, 1962, p. 34; Launius and Ulrich, NASA and the Exploration of Space, p. 43.

${ }^{28}$ Wolfe, The Right Stuff, p. 120

${ }^{29}$ Robert Gilruth Oral History No. 6 by David DeVorkin and John Mauer, March 2, 1987, Glennan-Webb-Seamans Project, National Air and Space Museum, Smithsonian Institution, Washington, DC.

${ }^{30}$ NASA Press Release, H00-127, "Dr. Robert Gilruth, An Architect Of Manned Space Flight, Dies," August 17, 2000, NASA Historical Reference Collection; Pearce Wright, "Robert Gilruth: Rocket Engineer who put Americans into Space," The Guardian (London, U.K.), August 20, 2000; Robert R. Gilruth, "To the Moon and Beyond," The Aeronautical Journal 75 (January 1971): 1-17; Allan C. Fisher Jr., "Exploring Tomorrow with the Space Agency," National Geographic, July 1960, pp. 48, 52-89; Kenneth F. Weaver, "Countdown for Space," National Geographic, May 1961, pp. 702-34.

${ }^{31}$ Christopher S. Wren, "Pete Conrad, 69, the Third Man to Walk on the Moon, Dies After a Motorcycle Crash," New York Times, July 10, 1999, p. C-15. 
${ }^{32}$ Alan B. Shepard Jr., "A Pilot's Story,” National Geographic 130 (September 1961): 432-44; The Astronauts Themselves, We Seven (New York: Simon and Schuster, 1962), Shepard wrote three sections, "The Urge to Pioneer," pp. 65-69; "What to do Until the Ship Comes," pp. 164-67; and "A Range Around the World," pp. 285-99; Alan B. Shepard Jr., "The Astronaut's Story of the Thrust into Space," Life, May 19, 1961; "Shepard's Space Saga," Naval Aviation News 42 (June 1961): 20-23; Roger D. Launius, "Alan B. Shepard Jr.," in Research Guide to American Historical Biography (Washington, DC: Beacham Publishing, 1991), 5:2742-48.

${ }^{33}$ Louden Wainwright, "The Old Pro Gets His Shot at the Moon," Life, July 31, 1970; R.M. Henry, "Alan Shepard, Reaching for the Stars," All Hands, April 1982, pp. 6-11; A.J. Hall, "Climb Up Cone Crater," National Geographic 140 (July 1971): 13648; Launius, "Alan B. Shepard Jr.," in Research Guide to American Historical Biography, 5:2742-48.

${ }^{34}$ Roger D. Launius, Frontiers of Space Exploration (Westport, CT: Greenwood Press, $20042^{\text {nd }}$ ed.), pp. ?.

${ }^{35}$ Ibid.

${ }^{36}$ Afro American, December 17, 1972.

37 There are several good studies of the spacesuit. See Lillian D. Kozloski, U.S. Space Gear: Outfitting the Astronaut (Washington, DC: Smithsonian Institution Press, 1993); Gary L. Harris, The Origins and Technology of the Advanced Extravehicular Space Suit (San Diego, CA: Univelt, Inc., 2001). For an exploration of the spacesuit's cultural meaning see, Debra Benita Shaw, "Bodies Out of this World: The Space Suit as Cultural Icon," Science as Culture 13 (March 2004): 123-44.

${ }^{38}$ Shaw, "Bodies Out of this World," p. 123.

${ }^{39}$ Ibid., p. 125.

${ }^{40}$ Susan Jeffords, Hard Bodies: Hollywood Masculinity in the Reagan Era (New Brunswick, NJ: Rutgers University Press, 1994).

${ }^{41}$ Donna J. Haraway, Simians, Cyborgs, and Women: The Reinvention of Nature (London: Free Association Nooks, 1991), pp. 181-82.

${ }^{42}$ Megan Stern, "Imagine Space Through the Inhuman Gaze," in S. Brewster, J.J. Joughlin, D. Owen, and R.J. Walker, eds., Inhuman Reflections: Thinking the Limits of the Human (Manchester, UK: Manchester University Press, 2000), pp. 203-16.

${ }^{43}$ Marina Benjamin, Rocket Dreams: How the Space Age Shaped Our Vision of a World Beyond (New York: Free Press, 2003), pp. 30-36.

${ }^{44}$ See Norman Mailer, Of a Fire on the Moon (Boston: Little, Brown, 1970).

${ }^{45}$ United States Senate, Committee on Aeronautical and Space Sciences, Apollo 13 Mission. Hearing, Ninety-first Congress, second session. April 24, 1970 (Washington, DC: Government Printing Office, 1970); United States Senate, Committee on Aeronautical and Space Sciences, Apollo 13 Mission. Hearing, Ninety-first Congress, second session. June 30,1970 (Washington, DC: Government Printing Office, 1970); Henry S.F. Cooper, Jr., Thirteen: The Flight that Failed (New York: Dial Press, 1973); "Four Days of Peril Between Earth and Moon: Apollo 13, Ill-Fated Odyssey," Time, April 27, 1970, pp. 14-18; "The Joyous Triumph of Apollo 13," Life 24 April 1970, pp. 28-36; NASA Office of Public Affairs, Apollo 13: "Houston, We've Got a Problem" (Washington, DC: NASA EP-76, 1970); Roger D. Launius, "E Pluribus Unum: Apollo 13 and American Unity," Quest: The History of Spaceflight Magazine 4 (Spring 1995): 20-23.

${ }^{46} \mathrm{Jim}$ Lovell and Jeffrey Kluger, Lost Moon: The Perilous Voyage of Apollo 13 (Boston: Houghton Mifflin Co., 1994); Gene Kranz, Failure is not an Option: Mission Control from Mercury to Apollo 13 and Beyond (New York: Simon \& Schuster, 2000).

${ }^{47}$ John Powers, "The Wrong Stuff," Washington Post, July 9, 1995.

${ }^{48}$ Tom D. Crouch, "Review of Apollo 13," Journal of American History 84 (December 1997): 1180-82, quote from p. 1181.

${ }^{49}$ Center for Cultural Studies and Analysis, "American Perception of Space Exploration: A Cultural Analysis for Harmonic International and The National Aeronautics and Space Administration," pp. 23-24, presentation to NASA, Washington, DC, April 21, 2004, copy in possession of author.

${ }^{50}$ For a stimulating discussion of this dynamic in American history see, William Strauss and Neil Howe, The Fourth Turning (New York: Broadway Books, 1996); William Strauss and Neil Howe, Generations: The History of America's Future, 1584 to 2069 (New York: William morrow, 1992). 